\title{
PENGEMBANGAN FORMULA NANO-FITOSOM SERBUK LIOFILISASI SEDUHAN TEH HITAM (Camellia sinensis L. Kuntze)
}

\author{
Patihul Husni $^{1}$, Kartika Puspitaningrum ${ }^{2}$ \\ ${ }^{1}$ Fakultas Farmasi Universitas Padjajaran, Sumedang, Jawa Barat, Indonesia \\ ${ }^{2}$ Jurusan Farmasi, Politeknik Kesehatan Bandung, Jawa Barat, Indonesia
}

\begin{abstract}
Abstrak
Nano-fitosom merupakan suatu teknologi nano yang digunakan untuk meningkatkan bioavailabilitas bahan aktif yang terkandung dalam tanaman dengan cara mengikat bahan aktif dengan fosfolipid yang memiliki sifat mirip dengan membran sel. Nano-fitosom dibuat dengan mencampurkan fitokonstituen dan fosfatidilkolin dalam perbandingan molar tertentu. Penelitian ini bertujuan untuk mengembangkan formula nano-fitosom serbuk liofilisasi seduhan teh hitam (Camellia sinensis L. Kuntze). Nano-fitosom diformulasikan dengan membuat tiga variasi perbandingan katekin:fosfatidilkolin:kolesterol mulai dari 1:1:0,2 (F1), 1:2:0,2 (F2), dan 1:3:0,2 (F3) dengan menggunakan metode refluks. Evaluasi nano-fitosom meliputi ukuran partikel, indeks polidispersitas, dan efisiensi penjerapan. Hasil evaluasi menunjukkan bahwa ukuran partikel nano-fitosom sekitar 52,1-101,9 nm dengan nilai indeks polidispersitas 0,309-0,404. Efisiensi penjerapan berkisar antara 6,7266\%-11,4317\% . Formula nano-fitosom dengan efisiensi penjerapan yang paling baik yaitu $\mathrm{F}_{3}$ dengan perbandingan molar katekin:fosfatidilkolin:kolesterol 1:3:0,2 dengan ukuran partikel sebesar $52,1 \pm 12,5 \mathrm{~nm}$, indeks polidispersitas 0,320 dan efisiensi penjerapan 11,4317 $\pm 0,3153 \%$. Analisis data menggunakan One-Way Anova menunjukkan bahwa terdapat pengaruh konsentrasi fosfatidilkolin terhadap efisiensi penjerapan secara signifikan $(\mathrm{p}<0,05)$.
\end{abstract}

Kata kunci: nano-fitosom, fosfatidilkolin, teh hitam, Camellia sinensis L. Kuntze

\section{Development of Nano-phytosome Formula of Brewed Black Tea (Camellia sinensis L. Kuntze) Lyophilization Powder}

\begin{abstract}
Nano-phytosome is a nanotechnology for increasing the bioavailability of active ingredient in the plant by binding the active ingredient with a phospholipid which has properties similiar to cell membrane. Nano-phytosome was made by mixing the phytoconstituent and phosphatidylcholine in particular molar ratio. The aim of this study was to develop nanophytosome formula of brewed black tea (Camellia sinensis L. Kuntze) lyophilization powder. Nano-phytosome was formulated in three variations of molar ratio of phytoconstituent:phosphatidylcholine:cholesterol (1:1:0.2 $\left(\mathrm{F}_{1}\right)$, 1:2:0.2 $\left(\mathrm{F}_{2}\right)$ and 1:3:0.2 $\left.\left(\mathrm{F}_{3}\right)\right)$ using reflux method. Evaluation of the nano-phytosome include particle size, polydispersity index, and entrapment efficiency. The study results showed that the particle size of nanophytosome was 52.1-101.9 nm with polydispersity index 0.309-0.404. Entrapment efficiency was approximately between $6.7266 \%-11.4317 \%$. The best entrapment efficiency of the nanophytosome formula was F3 which molar ratio of catechin: phosphatidylcholine: cholesterol 1:3:0.2 with $52.1 \pm 12.5 \mathrm{~nm}$ in diameter, 0.302 in polydispersity index and $11,4317 \pm 0,3153 \%$ in entrapment efficiency. Analysis data using One-Way Anova showed that the concentration of phosphatidylcholine influenced the entrapment efficiency significantly $(p<0.05)$.
\end{abstract}

Keywords: nano-phytosome, phosphatidylcholine, black tea, Camellia sinensis L. Kuntze 


\section{Pendahuluan}

Hiperurisemia merupakan suatu keadaan terjadinya peningkatan kadar asam urat di dalam tubuh yang melebihi batas normal sehingga dapat menyebabkan radang sendi akibat terdapatnya kristal Monosodium Urat Monohidrat (MSUM) yang mengendap di persendian. Keadaan seperti ini dinamakan artitis gout. Kristal urat tidak hanya dapat mengendap di organ vital lain, seperti ginjal, saluran kemih, dan jantung, sehingga hiperurisemia dapat menyebabkan komplikasi yang serius. ${ }^{1}$

Pengobatan konvensional untuk hiperurisemia adalah menggunakan allopurinol yang bekerja dengan cara mengganggu katabolisme purin melalui inhibisi enzim "xantin oksidase" (XO) yang mengubah hipoxantin menjadi xantin yang selanjutnya akan diubah menjadi asam urat. ${ }^{2}$ Meskipun allopurinol memiliki efektivitas yang baik terhadap penurunan kadar asam urat, namun penggunaan allopurinol seringkali menimbulkan efek samping seperti reaksi alergi kulit, gangguan pencernaan, sakit kepala, pusing, dan rambut rontok. ${ }^{3}$ Berdasarkan data tersebut, diperlukan suatu pengembangan obat dari bahan alam yang memiliki efek inhibisi xantin oksidase setara dengan allopurinol namun dengan efek samping lebih rendah.

Senyawa flavonoid dan alkaloid pada tanaman dapat berperan sebagai pengobatan pada hiperurisemia dengan cara menghambat enzim $\mathrm{XO} .{ }^{4} \mathrm{Teh}$, produk yang diperoleh dari daun Camellia sinensis L. Kuntze, merupakan salah satu tanaman yang memiliki sifat antioksidan yang kuat karena kandungan dari polifenolnya yang tinggi khususnya katekin dan flavonoid. ${ }^{5}$ Teh Hitam dari kelas I jenis Broken Orange Pekoe (BOP) memiliki aktivitas inhibisi XO paling besar dibandingkan dengan Teh Hitam dari kelas lainnya yaitu 61,58\%. ${ }^{6}$ Kemampuan Teh Hitam dalam menginhibisi enzim xantin oksidase disebabkan karena adanya kandungan katekin dan polifenol yang masing-masing sebesar 4,2 $\mathrm{g}$ dan 16,5 g dalam $100 \mathrm{~g}$ berat kering. ${ }^{7}$ Katekin yang terkandung dalam ekstrak Teh Hitam memiliki polaritas yang tinggi. Semakin tinggi polaritas suatu bahan aktif, maka sifatnya akan semakin hidrofilik, artinya obat tersebut akan memiliki bioavailabilitas yang rendah karena sulit untuk dapat menembus membran sel. ${ }^{8}$

Nano-fitosom merupakan suatu kompleks yang terbentuk antara fitokonstituen dengan fosfolipid yang memiliki sifat mirip dengan membran sel dimana fosfolipid memiliki kepala yang bersifat polar dan bagian ekor yang bersifat nonpolar. Fitokonstituen akan berikatan dengan bagian kepala dari fosfolipid. Fosfolipid yang sering digunakan dalam pembuatan fitosom adalah fosfatidilkolin. Nano-fitosom dibuat dengan mencampurkan fitokonstituen dengan fosfatidilkolin pada perbandingan molar tertentu (biasanya 1:1 hingga 1:3), sehingga akan menghasilkan suatu kompleks yang ikatannya lebih kuat karena 1 molekul fitokonstituen akan diikat oleh 1 molekul fosfatidilkolin. Metode yang dapat digunakan dalam pembuatan nano-fitosom antara lain metode solvent evaporation, refluks, salting out, dan liofilisasi. ${ }^{9}$

Dalam penelitian ini, akan dikembangkan pembuatan nano-fitosom ekstrak Teh Hitam menggunakan metode refluks dengan variasi perbandingan ekstrak dan fosfatidilkolin untuk mengetahui komposisi perbandingan molar yang akan menghasilkan nano-fitosom dengan efisiensi penjerapan yang paling tinggi.

\section{Metode}

Alat

Beaker glass $50 \mathrm{ml}$ (Pyrex), vial $10 \mathrm{ml}$ dan $30 \mathrm{ml}$, syringe $1 \mathrm{ml}$ dan $3 \mathrm{ml}$, membran filter $0,45 \mu \mathrm{m}$, sonikator, desikator, pipet tetes, labu ukur $5 \mathrm{ml}$ dan $25 \mathrm{ml}$, neraca analitik (Mettler Toledo), magnetic stirrer (Karl Kol 6 type HSCD4), heating mantle, kondensor (Pyrex), 
labu alas bulat (Pyrex), cawan petri, sentrifugator (Centurion Scientific K3 Series $\left.^{\circledR}\right)$, Delsa ${ }^{\mathrm{TM}}$ Nano particle size analyzer, KCKT (Shimadzu LC-20 AT ${ }^{\circledR}$ ).

\section{Bahan}

Fosfatidilkolin (Sigma Aldrich), kolesterol, serbuk liofilisasi seduhan Teh Hitam (Camellia sinensis) (Pusat Penelitian Teh dan Kina Gamboeng), aqua pro injection (Ika Pharmindo), diklorometan pro analisis (Merck), etanol 96\% pro analisis (Merck), asetonitril HPLC grade (Merck).

\section{Pembuatan Serbuk Liofilisasi Seduhan Teh Hitam}

Teh Hitam diseduh dengan menggunakan air panas dengan perbandingan 1:50 b/v selama 6 menit. $^{7}$ Hasil seduhan kemudian disaring untuk memisahkan filtrat dengan ampasnya. Filtrat yang didapat kemudian diliofilisasi dengan menggunakan freeze dryer.

\section{Pembuatan Nano-fitosom Serbuk Liofilisasi Seduhan Teh Hitam Tanpa Fosfatidilkolin (Kontrol Negatif)}

Serbuk liofilisasi seduhan Teh Hitam ditimbang sebanyak $5 \mathrm{mg}$ dan dilarutkan dengan menggunakan $10 \mathrm{ml}$ etanol $96 \%$ p.a kemudian dilakukan penentuan kadar katekin menggunakan KCKT.

\section{Formulasi Nano-fitosom Serbuk Liofilisasi Seduhan Teh Hitam}

Nano-fitosom diformulasikan dengan membuat tiga variasi perbandingan katekin:fosfatidilkolin:kolesterol mulai dari 1:1:0,2 (F1), 1:2:0,2 (F2), dan 1:3:0,2 (F3) dengan menggunakan metode refluks. Formula nano-fitosom dapat dilihat pada tabel 1 di bawah ini.

Tabel 1 Formula Nano-fitosom Serbuk Liofilisasi Seduhan Teh Hitam

\begin{tabular}{lccc}
\hline \multirow{2}{*}{ Bahan } & \multicolumn{3}{c}{ Katekin:Fosfatidilkolin:Kolesterol } \\
\cline { 2 - 4 } & F1 & F2 & F3 \\
\cline { 2 - 4 } & $(1: 1: 0,2)$ & $(1: 2: 0,2)$ & 5 \\
\hline Serbuk liofilisasi (mg) & 5 & $5,2)$ \\
Fosfatidilkolin (mg) & 4,3513 & 8,7027 & 13,0540 \\
Kolesterol (mg) & 0,3249 & 0,3249 & 0,3249 \\
Diklorometan p.a (ml) & 25 & 25 & 25 \\
Etanol 96\% p.a (ml) & 15 & 15 & 15 \\
Aquabidest (ml) & 20 & 20 & 20 \\
\hline
\end{tabular}

Serbuk liofilisasi ditimbang sebanyak $5 \mathrm{mg}$ untuk semua formula, kemudian dilarutkan dalam $10 \mathrm{ml}$ etanol $96 \%$ p.a. Fosfatidilkolin ditimbang sesuai dengan jumlah yang tertera pada tabel 3.2 dan kemudian dilarutkan dalam $5 \mathrm{ml}$ etanol $96 \%$ p.a. Kolesterol yang digunakan dalam penelitian ini bobotnya sangat kecil yakni hanya 0,3249 mg. Bobot tersebut tidak dapat ditimbang dengan menggunakan neraca analitik karena berat minimal yang dapat ditimbang adalah sebesar $1 \mathrm{mg}$ sehingga kolesterol dibuat dalam bentuk larutan stok. Sebanyak 12,5 mg kolesterol dilarutkan dengan diklorometan dalam labu ukur $25 \mathrm{ml}$. Konsentrasi larutan kolesterol tersebut adalah sebesar 0,5 $\mathrm{mg} / \mathrm{ml}$.

Serbuk liofilisasi dan fosfatidilkolin yang sudah dalam keadaan terlarut kemudian dicampurkan di dalam labu alas bulat. Wadah dibilas dengan menggunakan $2 \mathrm{ml}$ etanol $96 \%$ p.a. Ditambahkan larutan kolesterol $0,5 \mathrm{mg} / \mathrm{ml}$ ke dalam labu alas bulat sebanyak $650 \mu$ l. Setelah itu larutan direfluks pada suhu $70^{\circ} \mathrm{C}$ selama 3 jam.

Setelah proses refluks selesai, larutan dituangkan ke dalam cawan petri. 
Pelarut yang ada diuapkan dengan menggunakan hair dryer selama \pm 30 menit hingga terbentuk lapisan tipis fitosom pada permukaan cawan petri. Lapisan tipis tersebut kemudian disimpan di dalam desikator selama semalaman $( \pm 12$ jam $)$ untuk menghilangkan residu pelarut yang masih tersisa.

Dilakukan hidrasi terhadap lapisan tipis fitosom dengan menggunakan $20 \mathrm{ml}$ aquabidest dengan menggunakan magnetic stirrer selama 30 menit. Kemudian larutan dipindahkan ke dalam vial $20 \mathrm{ml}$ dan dilakukan pengecilan ukuran partikel dengan menggunakan proses ultrasonikasi selama 30 menit.

\section{Pembuatan Larutan Standar Katekin}

Larutan standar katekin dibuat dengan cara menimbang standar katekin sebanyak $5 \mathrm{mg}$, kemudian dilarutkan dengan menggunakan aquabidest dalam labu ukur $10 \mathrm{ml}$ dan dikocok hingga homogen. Larutan standar katekin yang dibuat memiliki konsentrasi 500 ppm.

\section{Penetapan Panjang Gelombang Maksimum Katekin}

Dari larutan standar 500 ppm, dibuat larutan standar kerja dengan konsentrasi 30 ppm. Larutan dibaca absorbansinya dengan menggunakan spektrofotometer UV-Vis pada panjang gelombang 200-400 nm. Absorbansi yang diperoleh dapat digunakan untuk menentukan $\lambda$ maksimum dari senyawa katekin. $\lambda$ maksimum tersebut digunakan untuk penetapan kadar katekin pada KCKT untuk penentuan persen penjerapan nanofitosom serbuk liofilisasi teh hitam yang telah dibuat.

\section{Optimasi Kondisi Analisis KCKT}

Kondisi KCKT yang digunakan antara lain kolom Phenomenex ${ }^{\mathrm{TM}}$, RP 18,5 $\mu \mathrm{m}, 4,6 \times 150 \mathrm{~mm}$, volume injeksi $20 \mu \mathrm{L}$ dengan kecepatan alir $0,5 \mathrm{~mL} / \mathrm{menit}$, temperatur kolom diatur pada $40,2^{\circ} \mathrm{C}$. Pembacaan kromatogram menggunakan detektor UV-Vis pada $\lambda 279 \mathrm{~nm}$. Fase gerak yang digunakan adalah campuran asetonitril dan aquabidest dengan menggunakan sistem elusi isokratik. Optimasi kondisi analisis KCKT dilakukan dengan mengubah perbandingan komposisi fase gerak dan laju alir hingga didapatkan kondisi optimal yang ditandai dengan hasil waktu retensi yang cepat serta kurva yang simetris dan terpisah.

\section{Uji Kesesuaian Sistem dan Pembuatan Kurva Kalibrasi}

Setelah kondisi optimal analisis didapatkan, langkah selanjutnya adalah dilakukannya uji kesesuaian sistem. Uji kesesuaian sistem dilakukan dengan cara menginjeksikan larutan standar katekin 30 ppm, kemudian parameter hasil yang didapat dibandingkan dengan syarat pada pustaka. Adapun parameter yang dinilai antara lain theoritical plate, resolusi, dan tailing factor.

Pembuatan kurva kalibrasi dilakukan dengan cara membuat larutan baku kerja konsentrasi 10, 20, 40, 60, 80, dan 100 ppm dari larutan baku katekin 500 ppm. Setelah itu dilakukan penetapan kadar dengan menginjeksikan setiap larutan baku ke KCKT. Luas area yang diperoleh diregresikan terhadap konsentrasi larutan untuk mengetahui rentang baku kerja yang digunakan untuk penetapan kadar katekin dalam sampel.

Kadar katekin dalam sampel dihitung dengan menggunakan rumus:

$$
\text { Kadar sesungguhnya }(\%)=\frac{\text { kadar yang terbaca } x \text { faktor pengenceran } x \frac{\text { vol.labu }}{1000}}{\text { mg sampel }} \times 100
$$




\section{Evaluasi Nano-fitosom Serbuk Liofilisasi Seduhan Teh Hitam}

\section{Ukuran dan Distribusi Ukuran Nano- fitosom}

Penetapan ukuran partikel dan distribusi ukuran partikel dilakukan dengan menggunakan metode electroporetic light scattering (Delsa ${ }^{\mathrm{TM}}$ Nano Particle Size Analyzer, Beckman Coulter, USA). Pengukuran sampel $(n=3)$ dilakukan dengan supernatan yang telah difiltrasi dimasukkan ke dalam kuvet dan kuvet disimpan dalam alat particel size analyzer. Dari hasil pengukuran diperoleh ukuran rata-rata partikel (berdasarkan number distribution) dan indeks polidispersitas partikel yang menggambarkan distribusi ukuran partikel.

\section{Efisiensi Penjerapan ${ }^{10}$}

Tujuan dari evaluasi ini adalah untuk mengetahui jumlah katekin yang terjerap di dalam nano-fitosom. Nanofitosom serbuk liofilisasi Teh Hitam disentrifugasi pada kecepatan 12000 rpm selama 45 menit $^{10}$ untuk memisahkan nano-fitosom dengan bahan aktif yang tidak terjerap. Konsentrasi bahan aktif yang tidak terjerap sebagai supernatannya diukur kadarnya dengan menggunakan KCKT. Kemudian dihitung persen penjerapan dengan menggunakan rumus:

$$
\text { Persen Penjerapan }(\%)=\frac{\text { kadar zat dalam nano-fitosom }}{\text { kadar zat teoritis }} \times 100
$$

\section{Hasil}

Hasil ekstraksi $20 \mathrm{~g}$ simplisia teh hitam yang telah diseduh dalam $1000 \mathrm{ml}$ aquadest didapatkan serbuk liofilisasi sebanyak 4,725 g dengan rendemen sebesar 23,625\% (dapat dilihat pada tabel 2). Kadar katekin yang terdapat di dalam serbuk liofilisasi seduhan teh hitam (Camellia sinensis) adalah sebesar $32,9325 \%$.

Hasil dari formulasi nano-fitosom serbuk liofilisasi seduhan teh hitam menunjukkan lapisan tipis yang merata pada formula 1 dan 3 , sedangkan pada formula 2 terdapat gelembung pada lapisan tipis yang terbentuk. Setelah dilakukan hidrasi terhadap lapisan tipis fitosom, didapatkan larutan nano-fitosom yang jernih berwarna kuning, dimana kepekatan warnanya semakin bertambah dengan meningkatnya kadar fosfatidilkolin yang ditambahkan dalam formula.

Pada penentuan panjang gelombang katekin menggunakan spektrofotometer UV-Vis didapatkan bahwa panjang gelombang katekin sebesar $279 \mathrm{~nm}$. Hasil optimasi kondisi analisis didapatkan bahwa kondisi analisis yang optimal untuk penelitian ini adalah menggunakan fase gerak asetonitril:aquabidest (20:80). Berdasarkan hasil uji kesesuaian sistem, didapatkan hasil bahwa sistem KCKT yang digunakan telah sesuai dan dapat digunakan untuk analisis senyawa katekin karena telah memenuhi persyaratan yang tertera dalam USP. Kurva kalibrasi didapatkan nilai $r$ sebesar 0,9969 dengan persamaan linearitas y=29343,6x-229295.

Pada evaluasi nano-fitosom didapatkan nano-fitosom dengan ukuran rata-rata diameter berada pada rentang 52,1-101,9 nm dengan indeks polidispersitas kurang dari 0,5. Efisiensi penjerapan yang paling tinggi dimiliki oleh nano-fitosom F3 yaitu sebesar $11,4317 \pm 0,3153 \%$.

\section{Pembahasan}

Simplisia teh hitam grade BOP diekstraksi dengan menggunakan metode penyeduhan yang dipilih sebagai metode ekstraksi karena sesuai dengan kebiasaan masyarakat Indonesia yang mengkonsumsi teh dengan cara diseduh dengan menggunakan air. Selain itu, katekin dalam teh hitam yang akan dijadikan bahan aktif dalam penelitian ini 
memiliki kelarutan yang tinggi jika diseduh dengan menggunakan air panas. ${ }^{11}$

Filtrat yang didapatkan dari hasil penyeduhan kemudian dikeringkan dengan menggunakan cara penguapan pelarut. Salah satu metode untuk penguapan pelarut adalah dengan liofilisasi. Metode ini digunakan untuk bahan-bahan dengan pelarut air. Pengeringan dengan metode liofilisasi dilakukan dengan menggunakan alat freeze dryer.

Tabel 2 Hasil Serbuk Liofilisasi Seduhan Teh Hitam $(\mathrm{n}=3)$

\begin{tabular}{cccc}
\hline Simplisia teh hitam $(\mathrm{g})$ & Aquadest $(\mathrm{ml})$ & Serbuk liofilisasi $(\mathrm{g})$ & Rendemen $(\%)$ \\
\hline 20 & 1000 & 4,725 & 23,625 \\
\hline
\end{tabular}

Pada tahap awal pengembangan formulasi, dilakukan optimasi dengan membuat nano-fitosom kosong. Proses pembuatan nano-fitosom kosong dilakukan dengan menggunakan metode refluks $^{12}$. Metode refluks ini dipilih karena merupakan metode yang sederhana dan tidak memerlukan peralatan yang canggih sehingga dapat dilakukan di laboratorium dengan peralatan yang sederhana. Tujuan dari tahap optimasi adalah untuk mengetahui metode pengeringan yang tepat sehingga lapis tipis fitosom dapat terbentuk. Lapis tipis yang terbentuk harus homogen dengan ketebalan yang merata karena akan mempengaruhi efisiensi dari proses hidrasi nano-fitosom.

Optimasi pengeringan dilakukan dengan menggunakan udara panas dan tidak. Pengeringan dengan udara panas dilakukan dengan menggunakan hair dryer dengan pengaturan jarak sedemikian rupa agar udara panas tidak langsung menyentuh cairan fitosom. Sedangkan pengeringan tanpa menggunakan udara panas dilakukan dengan menganginanginkan cairan nano-fitosom hingga seluruh pelarut yang ada menguap.

Tabel 3 Hasil Optimasi Pembentukan Lapisan Tipis Nano-fitosom

\begin{tabular}{lll}
\hline & FO1* & FO2* \\
\hline Fosfatidilkolim $(\mu \mathrm{mol})$ & 13,02 & 13,02 \\
Etanol p.a $(\mathrm{ml})$ & 6 & 6 \\
Proses refluks & $70{ }^{\circ} \mathrm{C}$ selama 3 jam & $70{ }^{\circ} \mathrm{C}$ selama 3 jam \\
Pengeringan & Udara panas & Tanpa udara panas \\
Lama pengeringan & 30 menit & 2 jam \\
Hasil lapisan tipis & Ketebalan merata pada permukaan & Ketebalan tidak merata pada \\
& cawan petri & permukaan cawan petri \\
\hline
\end{tabular}

*FO1 = Formula Optimasi 1, FO2 = Formula Optimasi 2

\section{Berdasarkan Tabel 3,} pembentukan lapisan tipis dengan menggunakan udara panas lebih cepat jika dibandingkan dengan tanpa menggunakan udara panas. Selain itu, penggunaan udara panas dalam tahap pengeringan menghasilkan lapisan tipis yang merata pada permukaan cawan petri, sedangkan pengeringan tanpa udara panas menghasilkan lapisan tipis yang tidak merata pada permukaan cawan petri, dimana terdapat sisi yang lebih lebih tebal dibandingkan sisi lainnya. Berdasarkan hasil optimasi tersebut, maka pada penelitian ini pembentukan lapisan tipis nano-fitosom dilakukan dengan menggunakan udara panas.

Sebelum dilakukan pengembangan formulasi, pertama-tama dilakukan penentuan kadar katekin yang terdapat di dalam serbuik liofilisasi seduhan Teh Hitam. Penentuan kadar katekin dalam serbuk liofilisasi seduhan Teh Hitam dilakukan dengan melarutkan $5 \mathrm{mg}$ serbuk 
liofilisasi seduhan Teh Hitam dengan etanol $96 \%$ p.a. dalam labu ukur $10 \mathrm{ml}$. Larutan yang telah homogen disaring dengan menggunakan membran filter 0,45 $\mu \mathrm{m}$ lalu diinjeksikan ke sistem KCKT untuk melihat luas area yang terbaca. Setelah diinjeksikan, didapatkan luas area sampel katekin dalam serbuk liofilisasi teh hitam sebesar 3744140. Nilai tersebut lebih besar dibandingkan dengan luas area standar katekin dengan konsentrasi terbesar dalam kurva kalibrasi yaitu konsentrasi 100 ppm yang memiliki luas area 2785610. Hal tersebut menyebabkan kadar katekin dalam serbuk liofilisasi tidak dapat dihitung akibat tidak masuk ke dalam rentang konsentrasi kurva kalibrasi sehingga perlu dilakukan pengenceran.

Larutan serbuk liofilisasi Teh Hitam dilakukan pengenceran sebanyak 5 kali dan di saring dengan membran filter $0,45 \mu \mathrm{m}$ dan diinjeksikan ke sistem KCKT. Setelah diinjeksikan, didapatkan hasil luas area sampel sebesar 737064. Luas area tersebut kemudian dimasukkan ke dalam persamaan regresi untuk menentukan kadar katekin yang terdapat dalam serbuk liofilisasi teh hitam. Setelah dilakukan perhitungan, kadar katekin yang terkandung di dalam serbuk liofilisasi teh hitam adalah $32,9325 \%$. Kadar katekin tersebut digunakan untuk mengetahui perbandingan mol komponen yang digunakan dalam formula dan untuk menghitung persen penjerapan nanofitosom.

Tahapan selanjutnya adalah pengembangan formulasi nano-fitosom dengan dilakukannya penambahan bahan aktif dan kolesterol. Penambahan kolesterol dalam formula dapat meningkatkan stabilitas nano-fitosom karena adanya interaksi antara kolesterol dan fosfatidilkolin yang menyebabkan struktur nano-fitosom menjadi lebih rigid. ${ }^{13}$

Pembentukan

nano-fitosom

dilakukan dengan mencampurkan bahan aktif (katekin dalam serbuk liofilisasi), fosfatidilkolin, dan kolesterol dalam perbandingan molar 1:1:0,2 hingga 1:3:0,2 untuk mengetahui pada perbandingan berapa akan terbentuk nano-fitosom dengan efisiensi penjerapan yang paling tinggi. Langkah pertama dalam pembuatan nano-fitosom adalah penimbangan bahan dan pelarutan bahanbahan menggunakan pelarut yang sesuai. Serbuk liofilisasi teh hitam dan fosfatidilkolin dilarutkan dengan menggunakan etanol $96 \%$ p.a., sedangkan kolesterol dilarutkan dalam diklorometan p.a. Penggunaan pelarut organik untuk melarutkan bahan-bahan bertujuan untuk lebih memudahkan penguapan pelarut saat akan dibentuknya lapisan tipis nanofitosom.

Setelah masing-masing bahan dalam keadaan terlarut, semua bahan dimasukkan ke dalam labu alas bulat untuk kemudian direfluks selama 3 jam pada suhu $70^{\circ} \mathrm{C}$. Kemudian, larutan dituangkan ke dalam cawan petri dan dilakukan pengeringan dengan menggunakan udara panas (hair dryer) hingga seluruh pelarut menguap dan terbentuk lapisan tipis pada permukaan cawan petri. Kemudian cawan petri disimpan di dalam desikator selama semalaman $( \pm 12$ jam $)$ dengan tujuan agar residu pelarut yang masih tersisa dapat teruapkan. Dari hasil pengeringan didapatkan lapisan tipis nano-fitosom yang tersebar merata di permukaan cawan petri, akan tetapi terdapat gelembung pada lapisan tipis formula 2. Terbentuknya gelembung pada lapisan tipis akan mempengaruhi efisiensi penjerapan yang dihasilkan. Kemudian dilakukan hidrasi dengan menggunakan $20 \mathrm{ml}$ aquabidest dan dilakukan pengecilan ukuran partikel dengan proses sonikasi selama 30 menit. Setelah dilakukan hidrasi, didapatkan larutan nano-fitosom berwarna kuning yang kepekatannya semakin tinggi seiring dengan bertambahnya kadar fosfatidilkolin yang ditambahkan. Nanofitosom yang telah dibuat kemudian dievaluasi yang meliputi ukuran dan 
distribusi ukuran partikel serta efisiensi penjerapan.

Pengujian ukuran dan distribusi ukuran partikel fitosom dilakukan dengan menggunakan alat Delsa ${ }^{\mathrm{TM}}$ Nano particle size analyzer pada suhu $25^{\circ} \mathrm{C}$, terhadap seluruh formula. Dari hasil pengujian akan didapatkan nilai diameter rata-rata partikel dan indeks polidispersitas dari nanofitosom yang dibuat.

Tabel 4 Hasil Pengujian Diameter Rata-Rata Partikel Nano-fitosom ( $\mathrm{n}=3$ )

\begin{tabular}{ccc}
\hline Formula & Diameter $(\mathrm{nm})$ & Indeks polidispersitas \\
\hline F1 & $65,4 \pm 18,3$ & 0,404 \\
F2 & $101,9 \pm 27,9$ & 0,309 \\
F3 & $52,1 \pm 12,5$ & 0,320 \\
\hline
\end{tabular}

*Rata-rata \pm standar deviasi

Berdasarkan tabel 4, ukuran ratarata diameter partikel nano-fitosom berada pada rentang 52,1-101,9 $\mathrm{nm}$ dengan indeks polidispersitas kurang dari 0,5. Nilai indeks polidispersitas merupakan nilai yang menunjukkan penyebaran distribusi ukuran partikel. Indeks polidispersitas yang baik berada pada rentang 0-0,5. Semakin kecil nilai indeks polidispersitas, maka semakin seragam ukuran partikel suatu sampel ${ }^{14}$. Hasil tersebut menunjukkan bahwa rata-rata diameter partikel nano-fitosom yang dibuat sesuai dengan ukuran rata-rata diameter partikel hasil kompleksasi antara bahan aktif pada tanaman dengan fosfatidilkolin berada pada rentang $50 \mathrm{~nm}$ - $500 \mu \mathrm{m} .{ }^{15}$

Berdasarkan hasil evaluasi ukuran dan distribusi ukuran partikel, nanofitosom yang dibuat telah memenuhi kriteria inklusi yang ditetapkan yaitu ukuran partikel $\leq 200 \mathrm{~nm}$ dengan indeks polidispersitas 0-0,5. Oleh karena itu, dapat dilakukan evaluasi efisiensi penjerapan terhadap nano-fitosom yang telah dibuat.

Evaluasi efisiensi penjerapan dilakukan dengan menggunakan instrumen KCKT. Sebelum dilakukan optimasi kondisi analisis, dilakukan penetapan panjang gelombang maksimum katekin dengan menggunakan spektrofotometer UV-Vis. Dari larutan standar katekin 500 ppm, kemudian dibuat larutan standar kerja 30 ppm untuk discan pada panjang gelombang 200-400 nm. Panjang gelombang tersebut dipilih karena katekin memiliki gugus kromofor berupa ikatan rangkap terkonjugasi, dimana gugus ini akan menyerap atau mengabsorbsi radiasi elektromagentik di daerah panjang gelombang UV dan visible.

Setelah dilakukan pengukuran, didapatkan bahwa katekin memiliki serapan maksimum pada panjang gelombang $279 \mathrm{~nm}$, hasil tersebut sesuai dengan panjang gelombang maksimum yang tertera pada pustaka yaitu sebesar $280 \mathrm{~nm}^{16}$ Berdasarkan hasil tersebut, panjang gelombang $279 \mathrm{~nm}$ digunakan untuk analisis kadar katekin pada sampel dengan menggunakan KCKT.

Kondisi optimum untuk analisis katekin dalam sampel dilakukan dengan cara mengoptimasi kondisi analisisis pada sistem KCKT Shimadzu LC-20 AT Prominance $^{\circledR}$ dengan parameter yang dioptimasi meliputi perbandingan komposisi fase gerak. Fase gerak yang digunakan untuk analisis katekin menggunakan KCKT adalah asetonitril dan dapar fosfat $1 \mathrm{M}$ dengan perbandingan 15:85. Pada penelitian ini, penggunaan dapar fosfat sebagai fase gerak digantikan dengan aqubiadest. Penggunaan dapar dalam analisis menggunakan KCKT berisiko mengurangi efisiensi kolom. Dapar terbuat dari asam atau basa dengan garamnya dan garam tersebut memiliki sifat cepat mengkristal sehingga dapat menyumbat kolom. Optimasi kondisi analisis dilakukan dengan mengubah 
perbandingan fase gerak yang digunakan,

$15: 85$

10:90

dan

20:80. yaitu asetonitril:air pada perbandingan

Tabel 5 Hasil Optimasi Kondisi Analisis Katekin Menggunakan KCKT

\begin{tabular}{c|c|c|c}
\hline Kondisi & 1 & 2 & 3 \\
\hline Kolom & Inertsil-OD3 $\mathrm{C}_{18}$ & Inertsil-OD3 $\mathrm{C}_{18}$ & ${\text { Inertsil-OD3 } \mathrm{C}_{18}}$ \\
Sistem elusi & Isokratik & Isokratik & Isokratik \\
Fase Gerak & Asetonitril:Air & Asetonitril:Air & Asetonitril:Air \\
& $(15: 85)$ & $(10: 90)$ & $(20: 80)$ \\
Laju Alir & $0,5 \mathrm{ml} / \mathrm{menit}$ & $0,5 \mathrm{ml} / \mathrm{menit}$ & $0,5 \mathrm{ml} / \mathrm{menit}$ \\
Detektor & $\mathrm{UV}-\mathrm{VIS}$ & $\mathrm{UV}-\mathrm{VIS}$ & UV-VIS \\
$\Lambda$ & $279 \mathrm{~nm}$ & $279 \mathrm{~nm}$ & $279 \mathrm{~nm}$ \\
Waktu Retensi & $11,5 \mathrm{menit}$ & $25,3 \mathrm{menit}$ & 7 menit \\
\hline
\end{tabular}

Berdasarkan tabel 5, komposisi fase gerak asetonitril dan aquabidest pada perbandingan 20:80 merupakan kondisi terbaik karena menghasilkan waktu retensi yang paling cepat jika dibandingkan dengan kondisi yang lain, yakni 7 menit. Berdasarkan hal tersebut, maka analisis katekin dalam sampel dilakukan dengan menggunakan fase gerak asetonitril dan aquabidest pada perbandingan 20:80.

Setelah didapatkan kondisi analisis yang sesuai, maka langkah selanjutnya adalah dilakukan uji kesesuaian sistem dengan membandingkan parameter hasil analisis dengan persyaratan yang ditetapkan dalam kompendial USP 30.

Tabel 6 Parameter Uji Kesesuaian Sistem

\begin{tabular}{clccc}
\hline No. & \multicolumn{1}{c}{ Parameter } & Syarat & Hasil Analisis & Keterangan \\
\hline 1 & Lempeng teoritis & $\geq 1000$ & 3342,598 & MS \\
2 & Tailing factor & $\leq 2$ & 1,375 & MS \\
3 & Resolusi & $\geq 1,5$ & 1,724 & MS \\
4 & Faktor kapasitas & $1-10$ & 1,77 & MS \\
\hline
\end{tabular}

*MS = Memenuhi syarat

Pada tabel 6, dapat dilihat bahwa semua parameter analisis memenuhi persyaratan yang ditentukan dalam kompendial USP 30 sehingga dapat dikatakan bahwa sistem KCKT yang digunakan telah sesuai dan dapat digunakan untuk analisis kadar katekin dalam sampel.

Selanjutnya dibuat kurva kalibrasi dari larutan baku katekin. Kurva kalibrasi katekin dibuat dengan cara mengencerkan larutan baku katekin 500 ppm menjadi enam varian konsentrasi, yaitu 10 ppm, 20 ppm, 40 ppm, 60 ppm, 80 ppm, dan 100 ppm. Pemilihan rentang varian konsentrasi didasarkan pada kemungkinan kadar katekin pada sampel yang terbaca dimana kadar sampel yang terbaca harus masuk di dalam rentang varian konsentrasi kurva kalibrasi. Larutan dengan berbagai konsentrasi tersebut kemudian disaring dengan menggunakan membran filter 0,45 $\mu \mathrm{m}$ dan kemudian diinjeksikan ke KCKT untuk mengetahui luas area dari setiap varian konsentrasi. Setelah itu, dibuat kurva kalibrasi dengan menghubungkan antara luas area kromatogram setiap titik (y) dengan varian konsentrasi (x).

Berdasarkan hasil penentuan kurva kalibrasi didapatkan nilai $\mathrm{r}$ yang hampir mendekati angka 1, yaitu 0,9969 yang berarti ada hubungan yang linier antara luas area yang terbentuk dengan konsentrasi yang terbaca. Persamaan linearitas dari kurva kalibrasi katekin yaitu $y=29343,6 x-229295$. Persamaan linearitas tersebut digunakan untuk mendapatkan nilai konsentrasi yang terbaca oleh detektor KCKT. 
Evaluasi penentuan efisiensi penjerapan nano-fitosom dilakukan untuk mengetahui seberapa besar kemampuan nano-fitosom yang dibuat untuk menjerap katekin. Pada evaluasi ini, sampel nanofitosom yang telah dihidrasi dilakukan sentrifugasi dengan kecepatan $12000 \mathrm{rpm}$ selama 45 menit. Proses sentrifugasi ini bertujuan untuk mengendapkan katekin yang terjerap dalam kompleks nanofitosom sehingga pada bagian supernatannya hanya akan mengandung katekin yang tidak terjerap. Bagian supernatan tersebut kemudian disaring dengan menggunakan membran filter 0,45 $\mu \mathrm{m}$ dan diinjeksikan ke sistem KCKT.

Tabel 7 Hasil Pengujian Efisiensi Penjerapan Katekin dalam Nano-fitosom ( $\mathrm{n}=3$ )

\begin{tabular}{cc}
\hline Formula & Efisiensi penjerapan $(\%)$ \\
\hline F1 & $6,7266 \pm 0,6460$ \\
F2 & $7,4799 \pm 2,8091$ \\
F3 & $11,4317 \pm 0,3153$ \\
\hline
\end{tabular}

*Rata-rata \pm standar deviasi

Berdasarkan hasil yang tercantum pada tabel diatas dapat dilihat bahwa efisiensi penjerapan nano-fitosom tertinggi terdapat pada $\mathrm{F}_{3}$ yaitu sebesar $11,4317 \pm 0,3153$. Hal tersebut disebabkan oleh fosfatidilkolin yang tersedia lebih banyak dibandingkan pada formula lain, sehingga interaksi antara katekin dalam serbuk liofilisasi Teh Hitam (Camellia sinensis) dengan fosfatidilkolin semakin tinggi dan dapat meningkatkan ikatan katekin dalam kompleks nano-fitosom.

Data hasil evaluasi efisiensi penjerapan dianalisis secara statistik. Data efisiensi penjerapan diuji normalitas dan homogenitsnya. Suatu data dikatakan berdistribusi normal apabila nilai $p$-value $>0,05$. Berdasarkan uji normalitas, data efisiensi penjerapan pada semua formula dikatakan berdistribusi normal. Hasil uji normalitas dapat dilihat dalam Lampiran 15. Suatu data dikatakan homogen apabila didapat nilai $p$-value $>0,05$. Uji homogenitas data menunjukkan bahwa data yang digunakan homogen karena nilai p-valuenya adalah 0,089 .
Berdasarkan uji normalitas dan uji homogenitas data, data berdistribusi normal dan homogen. Sehingga pengujian statistik dapat dilakukan dengan menggunakan uji Anova dengan taraf kepercayaan $95 \%$.

Uji Anova menunjukkan nilai $p$ value 0,000. Hipotesis nol pada uji Anova adalah tidak ada pengaruh konsentrasi fosfatidilkolin terhadap efisiensi penjerapan nano-fitosom serbuk liofilisasi seduhan teh hitam. Sedangkan hipotesis alternatifnya adalah ada pengaruh konsentrasi fosfatidilkolin terhadap efisiensi penjerapan nano-fitosom serbuk liofilisasi seduhan teh hitam. Dengan menggunakan $\alpha=0,05$, dari hasil tersebut maka hipotesis nol ditolak. Oleh karena itu, dapat dikatakan bahwa ada pengaruh konsentrasi fosfatidilkolin terhadap efisiensi penjerapan nano-fitosom serbuk liofilisasi teh hitam. Namun, belum diketahui kelompok mana yang berbeda signifikan antara satu dengan lainnya, sehingga harus dilakukan uji banding ganda/Post

Hoc.

Tabel 8 Signifikansi Perbedaan Rata-Rata Efisiensi Penjerapan

\begin{tabular}{ccccc}
\hline Formula & F0 & F1 & F2 & F3 \\
\hline F0 & - & $0,002^{*}$ & $0,001^{*}$ & $0,000^{*}$ \\
F1 & - & - & 0,917 & $0,017^{*}$ \\
F2 & - & - & - & $0,041^{*}$ \\
F3 & - & - & - & - \\
\hline
\end{tabular}

*Berbeda signifikan 
Pada hasil uji Post Hoc terlihat perbedaan signifikan pada $\alpha<0,05$ yang ditandai dengan tanda $*$ sehingga dapat dikatakan bahwa ada perbedaan yang signifikan antara kelompok kontrol dengan F1, F2, dan F3; F1 dan F3; dan F2 dan F3.

\section{Kesimpulan}

Formula yang menghasilkan nano-fitosom dengan efisiensi penjerapan yang paling baik yaitu $\mathrm{F}_{3}$ dengan perbandingan molar katekin:fosfatidilkolin:kolesterol 1:3:0,2

\section{Daftar Pustaka}

1. Soeroso J, Algristian H. Asam Urat. Cetakan I. Depok: Penebar Plus; 2008.

2. Ronco C, Rodeghiero F. Hyperuricemic Syndromes: Pathophysiology and Therapy. Dalam Karger. London; 2005.

3. Tjay HT, Rahardja K. Obat-obat Penting. Edisi 6. Jakarta: Elex Media Komputindo; 2010.

4. Yulianto D. Inhibisi Xantin Oksidase Secara In Vitro oleh Ekstrak Rosela (Hibiscus sabdariffa) dan Ciplukan (Physais angulata) (Skripsi). Bogor: Institut Pertanian Bogor; 2009.

5. Jimenez AP, et al. The Effect of Dietary Methionine and White Tea on Oxidative Status of Gilthead Sea Bream (Sparus aurata). British Journal of Nutrition. 2012; 108:12021209.

6. Rohdiana D, et al. Xanthine Oxidase Inhibitory and Immunomodulatory Activities of Fifteen Grades Indonesia Orthodox Black Tea. International Journal of Pharmacy and Pharmaceutical Sciences. 2014; 6.

7. Rohdiana D. Teh: Proses, Karakteristik, \& Komponen Fungsionalnya. Food Review Indonesia. 2015; 10 (8). dimana menghasilkan ukuran partikel sebesar 52,1 $\pm 12,5 \quad \mathrm{~nm}$, indeks polidispersitas 0,320 dan efisiensi penjerapan $11,4317 \pm 0,3153 \%$.

\section{Saran}

Perlu dilakukan pengembangan lebih lanjut terhadap formulasi nanofitosom serbuk liofilisasi seduhan Teh Hitam (Camellia sinensis) sehingga didapatkan formula nano-fitosom yang reprodusibel dan efisiensi penjerapan yang lebih baik.

8. Katzung BG, et al. Basic and Clinical Pharmacology. Edisi 12. London: Mc Graw Hill Education; 2012.

9. Freag MS, et al. Lyophilized Phytosomal Nanocarriers as Platforms for Enhanced Diosmin Delivery: Optimization and Ex Vivo Permeation. International Journal of Nanomedicine. 2013; 8:2385-2397.

10. Sumanthi A, Senthamarai R. Design and Development of Phytosomes Containing Methanolic Extracts of Nymphea Nouchali and Trischosanthes Dioica. World Journal of Pharmaceutical Research. 2015.

11. Heroniaty. Sintesis Senyawa Dimer Katekin dari Ekstrak Teh Hijau dengan Menggunakan Katalis Enzim Peroksidase Dari Kulit Bawang Bombay (Allium Cepa) (tesis). Jakarta: Universitas Jakarta; 2012.

12. Das MK, Bhupen K. Design and Evaluation of Phyto-Phospolipid Complexes (Phytosomes) of Rutin for Transdermal Application. Journal of Applied Pharmaceutical Science. 2014.

13. Rasaie S, et al. Nano Phytosomes of Quercetin: A Promising Formulation Fortification of Food Products with Antioxidants. Pharmaceutical Sciences. 2014. 
14. Yuan Y, et al. Characterization and Stability Evaluation of $\beta$-Carotene Nonoemulsion Prepared by High Pressure Homogenization under Various Emulsfying Conditions. Food Research International.2008; 41:6168.

15. Khan J, et al. Review Recent Advances and Future Prospect of
Phyto-Phospolipid Complexation Technique for Improving Pharmacokinetic Profile of Plant Actives. Journal of Controlled Release. 2013.

16. Robinson T. Kandungan Senyawa Organik Tumbuhan Tinggi. Bandung: Penerbit ITB; 1995 